Theories \& Applications, the International Edition

Printed Version: (ISSN 2090-5262)

Online Version: (ISSN 2090-5270)

November 2012, Volume 2, No. 3 Pages (48 - 55)

\title{
The Effect of a Recommended Exercise Program on Some Physical and Psychological Variables for Lower Limb Disabled Children
}

\author{
Azza Ibrahim Khalil Mohamed*, Wael Kamel Mohamed Elhawy**
}

\begin{abstract}
:
Exercise programs were proved to be very important for disabled population as it helps in compensating some abilities that were naturally lost due to the nature of the disability. This is why researchers in the field of disability and sports always care about developing programs to increase the ability of movement and mobility for disabled people in addition to enhancing their psychological state, especially children as the importance of these programs in childhood is more than its importance for adults. The researcher aims for developing some physical and psychological variables for Lower limb disabled children from 9 to 12 years old $(n=20)$ through an exercise program "free and with tools". The physical variables were chosen and determined through a questionnaire that was distributed among academic experts and Paralympics coaches. The researchers used the experimental method on one group using pre, intra and post measurements to measure muscular strength (Maximum static strength - Power), Maximum arms speed and muscular power for arms. In addition to measuring the rate of physical self esteem as one of the most important psychological characteristics for disabled populations through a newly designed questionnaire that was proved reliable for measuring this variable. The results showed the presence of significant differences between pre, intra and post measurements in the values of strength, power and speed in favor of the intra measurement against the pre measurement and in favor of the post measurement against the pre and intra measurements. Also, the presence of significant differences between pre, intra and post measurements in favor of the intra measurement against the pre measurement and in favor of the post measurement against the pre and intra measurements in the values of self esteem, which proves that the recommended program had a positive effect in developing the physical and psychological variables subject to study. The researchers recommend using exercise programs to develop different physical and psychological abilities for disabled children.
\end{abstract}

Keywords: exercise - physical - psychological - variables - disabled-children

\section{Introduction and research problem:}

$\mathrm{T}$ he importance of being involved in any physical or recreational activity varies according to the individual needs of everyone. As the needs of a disabled person differs from the needs of a normal person. The case of caring for disabled population is considered to be a

\footnotetext{
* Assistant Professor, Sports Training Department, Faculty of Physical Education, Tanta University, Egypt.

** Lecturer, Exercises and Gymnastics Training Department, Faculty of Physical Education for Boys, Alexandria University, Egypt.
}

human and civilized principle in all societies regardless the cultural of traditional differences among them where this principle emphasizes on giving them the opportunity to do their duties and take their rights in addition to their full involvement in their societies regardless the degree of their disability.

Physical activities that are based on some physical exercises either free or with tools in the form of recreational activities were proven to give a positive chance for proper social and psychological growth, as well as giving the concerned people enough experience that can 
help enhance the response of the disabled people to respond to the medical treatment. Also promotes the patient's ability to adapt with this new disability especially if it is accompanied with pain or psychological disorders.

The importance of this research is derived from the importance of the two physical and psychological variables to any disabled person, especially is he/she is a child so the researchers intended to investigate the effect of a recommended exercise program on some physical and psychological variables for lower limb disabled children.

Socially, the lower limb disabled children are a category that really needs utmost psychological and medical care from their surrounding communities. This will occur through plans for recreational activities and physical exercises "free - with tools" that will be interesting and attractive for the child to practice. Fathy (1982), Atiyat (1997), Moussa et al (1999) and Sedeek (2002) all agreed that all forms of physical exercise will help positively to enhance the mobile and physical ability for individuals : 4 ) ( 31-29:1) (32-24:2 ) (33-27: 3 ) ( 44-40

Moussa (1971) and also confirmed that group exercises helps in developing sensations and other physical elements like strength, especially if these exercise are performed in a competition mode to achieve a certain target for raising the concept of loyalty for the group. (139: 5)

Shuker (2002:6) also confirmed the importance of physical self-esteem as the wrong knowledge about this issue may lead to some behavioral disorders where the disabled person won't be able to transfer his optical information into kinetic outputs.

Chung (2003:7) confirmed the significant relationship between the concept of the physical shape and self-esteem as well as recommending conducting further researches to investigate the importance of physical self-esteem.

Many researchers e.g. Feinberg (2010:8) investigated the concept of physical self-esteem where they all confirmed that this concept has physiological, social and psychological constituents that reflect the child's attitude towards his physical image.
Psychologists clearly mentioned that when the child moves and plays when he aims to learn, Azza khalil (1997) confirmed that the child's capacity to understand is affected either positively or negatively with the type of his kinetic experience in his early years (161:9). As his attitude towards his surroundings and his ability to explain and express his behavior and his self-esteem when he is dealing with those surroundings and his readiness to discover in addition to his own physical shape confidence, all are related to the type of the opportunities that has been given to him to move and play during his first 7 to 8 years.

The physical shape can be defined as the range to how the individual can know his body parts and their function and the relation between these parts and the surrounding environment according to

Gallahue (2002) also defined physical shape as the concept that raises due to our observation for the movement of our body parts, the relation between them as well as their relation to the surrounding space. (118:10)

Thus there is a very strong relation between the physical shape self-esteem and movement and exercise for the healthy children which confirms the importance of this research as it deals with the same concept but for disabled ones as they have more need to have the chance to move and play to create better physical shape self-esteem that will help in:

- Increasing the child's understanding and ability to deal with his surroundings

- Increasing the ability of feeling others and self

- Developing the functions of sensations

- Developing the body movements which in turn affects other learning skills positively as in reading and writing. (Katie Smith (2010:11 )and Nicholas F. Taylor (2010:12)

\section{Research aim:}

This research aims for:

1. Designing a suggested program using free exercises "with and without tools" for lower limb disabled children from 9 to 12 years 
2. Investigating the effect of the suggested program on some physical and psychological variables for lower limb disabled children from 9 to 12 years

\section{Research hypothesis:}

1. The presence of significant differences between the pre, intra and post measurements for some physical variables for lower limb disabled children from 9 to 12 years in favor of intra measurement against pre measurement and in favor of post measurement against intra measurement.

2. Identification of the significant differences between the pre, intra and post measurements of the test of the body image and self-esteem questionnaire for lower limb disabled children from 9 to 12 years in favor of intra measurement against pre measurement and in favor of post measurement against intra measurement.

\section{Research procedures:}

\section{Research method:}

The researchers used the experimental method on one group using pre, intra and post measurements.

\section{Research sample:}

The sample for this study were picked up intentionally among the members of a governmental rehabilitation center aged 9-12 years old with a lower limb disability " $\mathrm{N}=20$ ".

\section{$1^{\text {st }}$ Pilot study:}

This pilot study was conducted to confirm the homogenous formation of the members of sample society through anthropometric, physical and psychological variables.

Table (1)

Statistical processing for proving the homogenous sample society for the pilot study " $N=20$ "

\begin{tabular}{|c|c|c|c|}
\hline $\begin{array}{l}\text { Statistical } \\
\text { processing }\end{array}$ & Age & Height & Weight \\
\hline Arithmetic mean & 12.19 & 137.95 & 32.45 \\
\hline Standard deviation & 0.97 & 9.35 & 0.408 \\
\hline Kolmogorov-Smirnov test & 1.022 & 0.904 & 0.88 \\
\hline $\mathrm{Z}$ test & 0.247 & 0.387 & 0.421 \\
\hline
\end{tabular}

Table (2)

The statistical significance for the physical variables for the research sample " $N=20$ "

\begin{tabular}{|c|c|c|c|c|c|c|c|}
\hline $\begin{array}{l}\text { Statistical } \\
\text { Significance }\end{array}$ & $\begin{array}{l}\text { Research } \\
\text { variables }\end{array}$ & $\begin{array}{c}\text { Measurement } \\
\text { unit }\end{array}$ & $\begin{array}{c}\text { Arithmetic } \\
\text { mean }\end{array}$ & $\begin{array}{l}\text { Standard } \\
\text { deviation }\end{array}$ & $\mathrm{S}$ & $\mathrm{K}$ & $\begin{array}{l}\text { Variation } \\
\text { coefficient }\end{array}$ \\
\hline \multirow{2}{*}{ Grip strength } & Right hand & $\mathrm{Kg}$ & 6.50 & 0.489 & 0.681 & 1.719 & 7.350 \\
\hline & Left hand & $\mathrm{Kg}$ & 7.500 & 0.512 & 0.00 & 2.235 & 0.0684 \\
\hline \multirow[b]{2}{*}{ Speed power } & Pushing to horizontal bare & Reps & 2.300 & 0.470 & 0.945 & 1.242 & 0.204 \\
\hline & $\begin{array}{l}\text { Throwing a } 2 \mathrm{~kg} \text { medical } \\
\text { ball with both hands }\end{array}$ & M & 1.549 & 1.651 & 0.525 & 0.072 & 1.0658 \\
\hline \multicolumn{2}{|c|}{$\begin{array}{c}\text { Maximum speed of running } 30 \mathrm{~m} \text { on a } \\
\text { wheelchair }\end{array}$} & $\mathrm{Sec}$ & 11.082 & 0.448 & 0.438 & 0.436 & 4.042 \\
\hline
\end{tabular}

The numerical value of $\mathrm{Z}$ at $0.05=1.96$ which confirms that there are no significant differences among the above mentioned variables.
Table (2) shows that all the values of the variation coefficients for the research variables are all between 0.247 and 7.350 which proves 
the homogenous formation of the research sample.

The researchers also used the physical shape self-esteem questionnaire which was previously proved honest, reliable and objective.

Test Validation:

\section{Concurrent Validity:}

The body image test (Prepared by Shuker), (2009:13) has been administered for the pilot sample members $(n=15)$. The linear correlation coefficient between the scores of this measurement and the criterion scores has been calculated. It has been found that the reliability

\section{Discrimination Validity:}

Item discrimination indices has been calculated and table (3) shows the results

Table (3)

Discrimination Indices of the Test Items

\begin{tabular}{|c|c|c|c|c|c|c|c|}
\hline $\begin{array}{c}\text { Discrimination } \\
\text { Index }\end{array}$ & $\begin{array}{c}\text { Item } \\
\text { No }\end{array}$ & $\begin{array}{c}\text { Discrimination } \\
\text { Index }\end{array}$ & $\begin{array}{c}\text { Item } \\
\text { No. }\end{array}$ & $\begin{array}{c}\mathrm{n} \\
\text { Index }\end{array}$ & $\begin{array}{c}\text { Item } \\
\text { No. }\end{array}$ & $\begin{array}{c}\text { Discrimination } \\
\text { Index }\end{array}$ & Item No. \\
\hline 0.6073 & 16 & 0.485 & 11 & 0.366 & 6 & 0.592 & 1 \\
0.525 & 17 & 0.433 & 12 & 0.646 & 7 & 0.485 & 2 \\
0.629 & 18 & 0.261 & 13 & 0.525 & 8 & 0.748 & 3 \\
0.445 & 19 & 0.285 & 14 & 0.638 & 9 & 0.445 & 4 \\
0.414 & 20 & 0.634 & 15 & 0.445 & 10 & 0.366 & 5 \\
\hline
\end{tabular}

Table (3) showed that all test items has discriminate between individuals effectively. acceptable discrimination indices and can

Table (4)

The Reliability Coefficients using Alpha Cronbach and Test re-test methods

\begin{tabular}{|c|c|c|c|c|c|}
\hline Item No. & $\begin{array}{c}\text { Alpha } \\
\text { cronbach }\end{array}$ & $\begin{array}{c}\text { Test - retest } \\
\text { coefficient }\end{array}$ & Item No. & $\begin{array}{c}\text { Alpha } \\
\text { Cronbach }\end{array}$ & $\begin{array}{c}\text { Test - retest } \\
\text { coefficient }\end{array}$ \\
\hline 1 & 0.878 & ${ }^{* *} 0.869$ & 11 & 0.882 & ${ }^{* *} 0.859$ \\
2 & 0.882 & ${ }^{* *} 0.873$ & 12 & 0.883 & ${ }^{* *} 0.877$ \\
3 & 0.872 & ${ }^{* *} 0.902$ & 13 & 0.888 & ${ }^{* *} 0.866$ \\
4 & 0.883 & ${ }^{* *} 0.888$ & 14 & 0.881 & ${ }^{* *} 0.895$ \\
5 & 0.885 & ${ }^{* *} 0.891$ & 15 & 0.877 & ${ }^{* *} 0.903$ \\
6 & 0.885 & ${ }^{* *} 0.867$ & 16 & 0.876 & ${ }^{* *} 0.869$ \\
7 & 0.877 & ${ }^{* *} 0.846$ & 17 & 0.880 & ${ }^{* *} 0.874$ \\
8 & 0.880 & ${ }^{* *} 0.819$ & 18 & 0.877 & ${ }^{* *} 0.884$ \\
9 & 0.877 & ${ }^{* *} 0.837$ & 19 & 0.883 & ${ }^{* *} 0.817$ \\
10 & 0.883 & ${ }^{* *} 0.844$ & 20 & 0.884 & ${ }^{* *} 0.837$ \\
\hline
\end{tabular}

The value of the correlation coefficient @ $0.01=0.641$

The previous table shows the reliability of each statement of the questionnaire which confirms that deleting any of these statements will affect the measurement tool negatively.

\section{$2^{\text {nd }}$ Pilot study:}

The second pilot study aimed for determining the main targets of this recommended exercise program with and without tools "free" through studying previous researches in the same field in addition to scientific lectures as well as asking for consultation from experts and physicians related to the field of disability.

Where previous research stated that the physical shape has 2 elements, physiological and psychological as the child plays and moves to learn and discover which means that his personality is affected with the type of his movement experience during his early years 
where the physical shape helps in increasing the child's understanding towards himself and his surroundings as well as developing the function of all senses.

So this pilot study helped in determining the required compensations that identified elements of the recommended program and its units.

\section{$3^{\text {rd }}$ pilot study:}

That was performed to determine the appropriate test for each variable using similar researches and consulting experts in the same field either trainers or physicians.

Experts and similar studies stated that the most important physical variables for lower limb disabled children are:

\section{Maximum arms' strength}

2. Power

\section{Maximum arms' speed}

In addition to determining the test for each physical variable as follows:

1. Measuring the arms' strength through measuring the grip strength using manometer.

2. Measuring the arms' power through throwing a $2 \mathrm{~kg}$ medicine ball in addition to pushing the horizontal bar.

3. Measuring the maximum arms' speed through running with the wheel chair with maximum speed for $30 \mathrm{~m}$.

These tests were proved reliable and objective as the coefficients of reliability for the tests were $0.98,0.99,0.94$ and 0.88 respectively.

\section{$4^{\text {th }}$ pilot study:}

It was conducted to check the suitability of these measurements to the sample society where these measurements were applied on 10 lower limb disabled children where 5 of them were chosen randomly among the main sample society and 5 children suffering from the same disability outside the sample society.

This pilot study showed the following results:

1. The contents of the recommended program suit the sample society as well as the suggested measurements.

2. This program can be applied any where indoors or outdoors.
3. When this program is applied recreationally, recovery should be put into consideration.

4. The psychological state of the disabled children should be the considered while applying this program.

5. Each disabled child can perform according to his ability and physical and psychological state.

6. The tools should suit the abilities of the sample society.

\section{The main experiment:}

The pre-measurement was applied on the research sample including the physical tests as well as the physical shape self-esteem questionnaire.

The researchers started applying the recommended program using physical exercise with and without tools on lower limb disabled children from 9 to 12 years old. The program aims for:

1. Developing the feeling of physical shape selfesteem for the research sample through decreasing the negative feelings for disabled children that raise due to this disability.

2. Developing the psychological state will occurs due to developing the physical abilities which will compensate the negative feelings that are related to disability.

The researches started applying the recommended exercise program units that were divided into 3 stages (warm up - main activity cool down activity), were 3 sessions were applied weekly with a total time of 75 minutes per session divided into $7.5 \mathrm{~m}$ for warm up and $60 \mathrm{~m}$ for the main activity $(25 \mathrm{~m}$ physical preparation and $35 \mathrm{~m}$ recreational exercise with and without tools) and a cool down for $7.5 \mathrm{~m}$. the program lasted for 16 weeks where an intrameasurement was taken after the end of the 8th week.

The pre-measurement was applied after the 16th week to evaluate the outcomes of the program either physiologically or psychologically according to the recommended measurement tests. 
Statistical processing:

The researchers used SPSS V. 17 to conduct the statistical processing for the research raw data using:
1. T test

2. Skewness and kurtosis

3. ANOVA

4. Coefficient of variation

\section{Results:}

Table (5)

The statistical significance between pre and intra measurements for the research physiological variables

\begin{tabular}{|c|c|c|c|c|c|c|c|c|}
\hline \multirow{2}{*}{\multicolumn{2}{|c|}{$\begin{array}{l}\text { Statistical } \\
\text { significance }\end{array}$}} & \multirow{2}{*}{$\begin{array}{c}\text { Measurement } \\
\text { unit }\end{array}$} & \multicolumn{2}{|c|}{ Pre-measurement } & \multicolumn{2}{|c|}{ Intra-measurement } & \multirow{2}{*}{$\begin{array}{c}\text { The } \\
\text { difference } \\
\text { between } \\
\text { means }\end{array}$} & \multirow[b]{2}{*}{$\mathrm{T}$} \\
\hline & & & Mean & SD & Mean & SD & & \\
\hline \multirow{2}{*}{$\begin{array}{c}\text { Grip } \\
\text { strength }\end{array}$} & Right hand & $\mathrm{Kg}$ & 6.650 & 0.489 & 8.400 & 0.680 & 1.750 & 17.616 \\
\hline & Left hand & $\mathrm{Kg}$ & 7.500 & 0.513 & 8.600 & 0.750 & 1.100 & 5.082 \\
\hline \multicolumn{2}{|c|}{ Running speed } & $\mathrm{Sec}$ & 11.082 & 0.448 & 9.628 & 0.147 & 1.454 & 13.691 \\
\hline \multicolumn{2}{|c|}{ Pushing the horizontal bar } & Reps & 2.300 & 0.470 & 4.550 & 0.510 & 2.250 & 14.047 \\
\hline \multicolumn{2}{|c|}{ Throwing medicine ball } & $\mathrm{M}$ & 1.549 & 1.651 & 2.604 & 0.573 & 1.055 & 8.197 \\
\hline
\end{tabular}

Table (5) shows the presence of statistical significant differences in favor of the intrameasurement against the pre-measurement as at the level of 0.05 , the values of $\mathrm{T}$ were 17.616, $5.082,13.69,14.047$ and 8.197 respectively. If we took the left grip strength test as an example to prove the improvement of this physical variable between the pre and intrameasurements, the pre-measurement showed a result of $7.500+/-0.513 \mathrm{~kg}$ that increased to $8.600+/-0.750 \mathrm{~kg}$ in the intra-measurement.
The researchers refers this improvement to the muscular strength exercise which are a main content of the recommended exercise program "with and without tools" which affected the strength of the muscles of the arms positively. Also the researchers observed that the statistical significance of the improvement of the left hand was more than the strength improvement in the right hand which can be referred to the nature of the lower limb disability.

Table (6)

The statistical significance between intra and post measurements for the research physiological variables

\begin{tabular}{|c|c|c|c|c|c|c|c|c|}
\hline \multirow{2}{*}{\multicolumn{2}{|c|}{ measurements }} & \multirow{2}{*}{$\begin{array}{c}\text { Measurement } \\
\text { unit }\end{array}$} & \multicolumn{2}{|c|}{$\begin{array}{c}\text { Intra } \\
\text { measurement }\end{array}$} & \multicolumn{2}{|c|}{$\begin{array}{c}\text { Post } \\
\text { measurement }\end{array}$} & \multirow{2}{*}{$\begin{array}{l}\text { The } \\
\text { difference } \\
\text { between } \\
\text { means }\end{array}$} & \multirow{2}{*}{$\mathrm{t}$} \\
\hline & & & Mean & SD & Mean & SD & & \\
\hline \multirow{2}{*}{$\begin{array}{c}\text { Grip } \\
\text { strength }\end{array}$} & Right hand & $\mathrm{Kg}$ & 8.400 & 0.680 & 10.400 & 0.680 & 2.00 & 12.329 \\
\hline & Left hand & $\mathrm{Kg}$ & 8.600 & 0.750 & 11.400 & 0.753 & 2.800 & 10.466 \\
\hline \multicolumn{2}{|c|}{ Running speed } & $\mathrm{Sec}$ & 9.628 & 0.147 & 8.899 & 0.272 & 0.729 & 12.649 \\
\hline \multicolumn{2}{|c|}{ Pushing the horizontal bar } & Reps & 4.550 & 0.510 & 7.000 & 0.725 & 2.450 & 12.352 \\
\hline \multicolumn{2}{|c|}{ Throwing medicine ball } & $\mathrm{M}$ & 2.604 & 0.573 & 2.783 & 0.156 & 0.179 & 1.515 \\
\hline
\end{tabular}

Table (6) shows the presence of significant statistical differences between the intra and post-measurement in all the applied physical tests as the values of $\mathrm{T}$ were $12.329,10.466$, $12.649 \& 12.352$ respectively that were significant at the level of 0.05 . This 
improvement can be referred to the positive effect of the recommended program. As the values of $\mathrm{T}$ were $12.329,10.466,12.649$ and 12.352 respectively which were significant at the level of 0.05 . The test of the repetitions of pushes to the horizontal bar showed the results of $4.550+/-0.510$ in the intra-measurement and $7.000+/-0.725$ in the post measurement which shows the improvement in the level of arms' power to compensate the loss of lower limbs which is confirmed also by Kamal et al.(1978)( as they stated that muscles are the main source of movements for human beings where muscular strength is related to motor ability with a direct proportion relation(58:14).

Table (7)

The statistical significance between pre and post measurements for the research physiological variables

\begin{tabular}{|c|c|c|c|c|c|c|c|c|}
\hline \multirow{2}{*}{$\begin{array}{l}\text { Statistical } \\
\text { significan }\end{array}$} & & \multirow[b]{2}{*}{ Measurement unit } & \multicolumn{2}{|c|}{ Pre-measurement } & \multicolumn{2}{|c|}{ Post measurement } & \multirow{2}{*}{$\begin{array}{c}\text { The } \\
\text { difference } \\
\text { between } \\
\text { means }\end{array}$} & \multirow[b]{2}{*}{$\mathrm{t}$} \\
\hline & $\begin{array}{r}\text { Physical } \\
\text { Measurements }\end{array}$ & & Mean & SD & Mean & SD & & \\
\hline \multirow{2}{*}{$\begin{array}{c}\text { Grip } \\
\text { strength }\end{array}$} & Right hand & $\mathrm{Kg}$ & 6.650 & 0.489 & 10.400 & 0.680 & 3.750 & 26.259 \\
\hline & Left hand & $\mathrm{Kg}$ & 7.500 & 0.513 & 11.400 & 0.753 & 3.900 & 22.132 \\
\hline \multicolumn{2}{|c|}{ Running speed } & $\mathrm{Sec}$ & 11.082 & 0.448 & 8.899 & 0.272 & 2.183 & 18.873 \\
\hline \multicolumn{2}{|c|}{ Pushing the horizontal bar } & Reps & 2.300 & 0.470 & 7.000 & 0.725 & 4.700 & 28.687 \\
\hline \multicolumn{2}{|c|}{ Throwing medicine ball } & $\mathrm{M}$ & 1.549 & 1.651 & 2.783 & 0.156 & 1.234 & 34.236 \\
\hline
\end{tabular}

Table (7) shows the significant statistical differences between the pre and post measurements in all physical variables at the level of 0.05 where the values of $\mathrm{T}$ were 26.259 , $18.873,28.687 \& 34.236$ respectively. This obvious improvement can be referred to the nature of the recommended exercise program that helped in developing all the physical variables for the sample society especially for the arms' strength that are considered to be the main and only usable limb for lower limb disabled children. This is also can be referred to the pleasure of being involved in this experiment and the feeling of improvement that was already delivered to the members of the sample society that gave them more courage that was reflected also on their general psychological state.

The same applies for the speed test as the result of the pre-measurement was $11.082+/-0.448$ sec and the post measurement was $8.899+/-$ 0.272 which also reflects the positive effect of the recommended program on the speed of covering the distance of $30 \mathrm{~m}$ with the wheelchair. This agrees with what El-Bek et al. (1996) mentioned as they stated that the arm's speed is the speed of motion of the arm when performing different moves like twisting, rotating, flexing and extending (281:15).

Table (8)

The statistical significance between pre, intra and post measurements for the research psychological variable

\begin{tabular}{|c|c|c|c|c|c|c|}
\hline & $\begin{array}{c}\text { Arithmetic } \\
\text { mean }\end{array}$ & SD & $\begin{array}{c}\text { Pre } \\
\text { measurement }\end{array}$ & $\begin{array}{c}\text { Intra } \\
\text { measurement }\end{array}$ & $\begin{array}{c}\text { Post } \\
\text { measurement }\end{array}$ & $\begin{array}{c}\text { LSD@ } \\
(0.05)\end{array}$ \\
\hline $\begin{array}{c}\text { Pre } \\
\text { measurement }\end{array}$ & 30.35 & 2.889 & & & & 0.548 \\
\hline $\begin{array}{c}\text { Intra } \\
\text { measurement }\end{array}$ & 36.95 & 2.964 & $* 6.600$ & & & \\
\hline $\begin{array}{c}\text { Post } \\
\text { measurement }\end{array}$ & 42.4 & 3.440 & $* 12.05$ & $* 5.450$ & & \\
\hline
\end{tabular}

Table (8) shows the presence of significant statistical differences between the intra and pre measurements in favor of the intra measurement and between the intra and post measurements in favor of the post measurement at the level of 0.05 for the questionnaire of measuring the physical shape self-esteem as one of the most 
important psychological factors for the lower limb disables children.

1. The recommended exercise program with and without tools has been built and applied for lower limb disabled children according to the experiences of the researchers in the field of recreational exercises. This program lead to developing the physical shape self-esteem for the lower limb disabled children from 9-12 years.

2. In spite of the fact that regular physical/sportive activity is an integral part of complex personal development and indispensable aspect of harmonic process of an individual socialization, it has been found that exercise and recreational activities have a positive effect on some physical and psychological variables for lower limb disabled children from 9-12 years

\section{Recommendations:}

1. Using the recommended exercise program "with or without tools" with lower limb disabled children to affect some physical and psychological variables positively according to this research's results and conclusions.

2. Applying further researches to investigate the effect of similar exercises recreational programs on other physical and psychological variables aiming for making the lives of these children more easier and optimistic.

3. The importance of dedicating daily period of time to conduct such activities in schools and rehabilitation centers who deal with lower limb disabled children.

4. Using physical and psychological measurements in schools and rehabilitation centers to assess the applied programs through determining their effect on lower limb disabled children.

\section{References:}

1. Fathy A. I., (1982): The effect of developing warm up and exercise in the PE lesson on the technical performance of gymnastics for primary school level, Ph. D thesis, Alexandria University, Egypt.
2. Khatab M. A.,( 1997) Sports exercise for girls, 8th ed, Dar El-maaref, Alexandria, Egypt.

3. Moussa F., Adel M. H.(1999): Exercise and sports shows, 9th ed, Dar El-maref, Alexandria, Egypt.

4. Tolan S. (2002): Theory and basics of exercises, The faculty of physical education, Alexandria university, Egypt.

5. Ibrahim F. M.,(1971): Physical fitness and sports training, Dar El-kotob, Alexandria, Egypt.

6. Shuker M. Z. (2002): Normal personal and volatile, El- nahda El-masria, Cairo, Egypt.

7. Chung P. (2003): Physical self-concept between PE major and non-PE major students, journal of Exercise Science and Fitness, 1(1), 41-46.

8. Feinberg E. B. (2010) : School Accommodations to Support Psychosocial

Functioning and Self-Esteem in Adolescents with

Long QT Syndrome, Philadelphia College of Osteopathic Medicine.

9. Khalil A.(1997) : Psychology of play in early childhood,(2002), Dar El-fekr El-araby , Cairo, Egypt.

10. Gallahue, L. D. (2002): Developmental physical education for today's children, 3rd edition,

Brown \& Benchmark (Madison)

11. Smith K.(2010): Arm toning exercises for developmental disabilities.

12. Shields N. and Taylor F. T. (2010): A student-led progressive resistance training program increases lower limb muscle strength in adolescents with Down syndrome: a randomised controlled trial; "Journal of Physiotherapy".

13. Shuker M. Z. (2009) :Body Image, Fourth edition, Egyptian Angelo.

14. Kamal A. and Hassanin M. S. (1978): Physical fitness and its components, Dar Elfekr, Cairo.

15. Khater A. and El-Bek A. (1996): Measurement in sports, 4th ed, dar El-maaref, Alexandria, Egypt. 
